\title{
ON-FARM EVALUATION OF ORANGE FLESHED SWEET POTATO VARIETIES UNDER ACIDIC SOIL OF NORTH-EAST REGION IN BANGLADESH
}

\author{
M. I. Nazrul \\ Senior Scientific Officer, On-Farm Research Division, Bangladesh Agricultural Research Institute (BARI) \\ "Corresponding Author, E-mail: mi_nazrul@yahoo.com; m.i.nazrul@gmail.com
}

(Received: 3 December 2018, Accepted: 26 February 2019)

Keywords: sweet potato, acid soil, genotypes, orange flesh, morpho-physiology

\begin{abstract}
An on-farm trial with four orange fleshed sweet potato varieties viz. BARI Mishti Alu-4, BARI Mishti Alu-8, BARI Mishti Alu-12, BARI Mishti Alu-13 including local check (Muli Alu) were evaluated at farming system research and development (FSRD) site, Jalalpur, Sylhet, Bangladesh during rabi season for two consecutive years (2016-2017 \& 2017-2018) under Surma-Kushiyara Floodplain of Bangladesh. The experiment was laid out in a randomized complete block design (RCBD) with six dispersed replications. The results revealed that the genotypes varied considerably in tuber root yields and yield attributing characters. Considering the average tuber root yield performance orange fleshed sweet potato varieties performed better than local variety (Muli Alu). However, among the varieties under studied BARI Mishti Alu-12 produced higher roots yield (40.63 $\mathrm{t} \mathrm{ha}^{-1}$ ) than the other tested varieties. Considering economic return, the highest gross margin (Tk. 5,65,110 ha-1) and benefit cost ratio $(5.50: 1.00)$ was also obtained from sweet potato var. BARI Mishti Alu-12 and the lowest returnfrom var. BARI Mishti Alu-4 with benefit cost ratio of 3.54. Though the local cultivar (Muli Alu) produced lower root yields but it provided considerable gross margin (Tk.3,76,240 )and $\operatorname{BCR}(3.99: 1.00)$ which closed to BARI Mishti Alu-12. It is due to higher demand of local cultivar with high price in the local market. Therefore, the genotypes BARI Mishti Alu-12 and local cultivar (Muli Alu) were found suitable for their better growth and yield under the acidic soils.
\end{abstract}

\section{Introduction}

Sweet potato (Ipomoea batatas L.) is one of the most important tuber crops in Bangladesh which can be used as substitute of cereal crops to meet the up food shortage.. The foliage has the potential for use as vegetable and animal feed (Otoo et al., 2001). It is the fourth important crop in Bangladesh after rice, wheat and potato (Delowar and Hakim, 2014). Orange-fleshed sweet potato (OFSP) varieties are rich in beta-carotene, while purple-fleshed ones are high in anthocyanin. These two important antioxidants thought to prevent chronic heart diseases and cancer (Teow et al., 2007). The orange flesh sweet potato has significant antioxidant activity, and can potentially improve vitamin-A status in children (Laurie et al, 2015; Hotz et al., 2012; Li and Mu, 2012; Burri, 2011). Emerging health benefits of the orange flesh sweet potato (OFSP) are substantial, making it an even more important food-especially for populations in danger of malnutrition (Aywa et al. 2013; Kaspar et al., 2013). The average yield and area coverage of sweet potato is quite low compared to world context. Sweet potato is a promising crop for some areas of Sylhet region. It is mainly 
cultivated by the marginal or subsistence farmers in a sporadic way in different river belts, char lands, deltas and seasonally inundated flood plains (Ahmed et al., 1998). Farmers cultivate sweet potato with traditional varieties after T. Aman rice or in land remain fallow with no or less care and input. For this reason sweet potato could not express its yield potentiality and resulting produced low root yield. Bangladesh Agricultural Research Institute (BARI) has developed some new varieties of sweet potato that have high yielding ability and also contain rich in carotene. Among the sweet potato varieties BARI Mishti Alu-4, BARI Mishti Alu8, BARI Mishti Alu-12 and BARI Mishti Alu-13 are high yield potentially and also contain higher amount of carotene. For increasing sweet potato yield and higher economic return along with the supplement of carotene to the consumer, farmer's need to cultivate high yielding carotene rich sweet potato varieties. Keeping these views in mind, the experiment was conducted to evaluate the performance of orange flesh sweet potato varieties in acidic soil of Sylhet.

\section{Materials and methods}

\section{Descriptions of the Experimental Locations}

An on-farm study was conducted at farming system research and development (FSRD) site, Jalalpur in Sylhet district during rabi season for two consecutive years (2016-2017 \& 2017-2018) under Surma-Kushiyara Floodplain soil of Bangladesh. The study area located between 244ㅇ \& $24^{\circ} 54^{\prime} \mathrm{N}$ Latitude and $91^{\circ} 47^{\prime} \& 91^{\circ} 98^{\prime} \mathrm{E}$ Longitude and on an altitude of 10 meters.

\section{Soil and climate}

The experimentation on orange flesh sweet potato varieties conducted at farmer's field to evaluate the performance of color flesh sweet potato varieties in acidic soil of Sylhet. The climate and soil of the selected plot was under subtropical climate having heavy rainfall during monsoon and scanty or very little shower during prolong dry winter season, high to medium high land, and well drained grey floodplain fertile soils of acidic in nature. Type of experimental soil is noncalcareous gray with low organic matter content (1.29\%), low soil pH (4.5-5.2), very low total $\mathrm{N}(0.06 \%)$, low content of $\mathrm{P}(8.59), \mathrm{K}(0.13)$ and $\mathrm{S}$ (9.14) where as $\mathrm{Zn}(1.22)$ and Boron (0.48) medium and optimum, respectively.

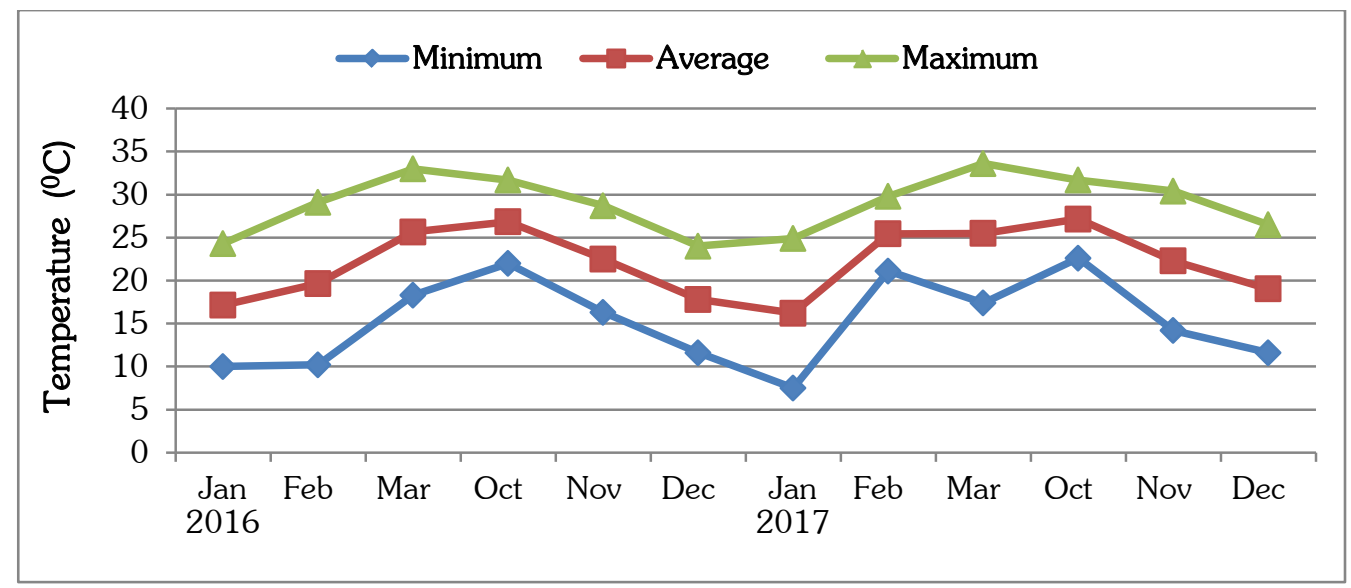

Fig. 1. Minimum, Maximum and average Temperature $\left({ }^{\circ} \mathrm{C}\right)$ pattern in experimental location of Sylhet 


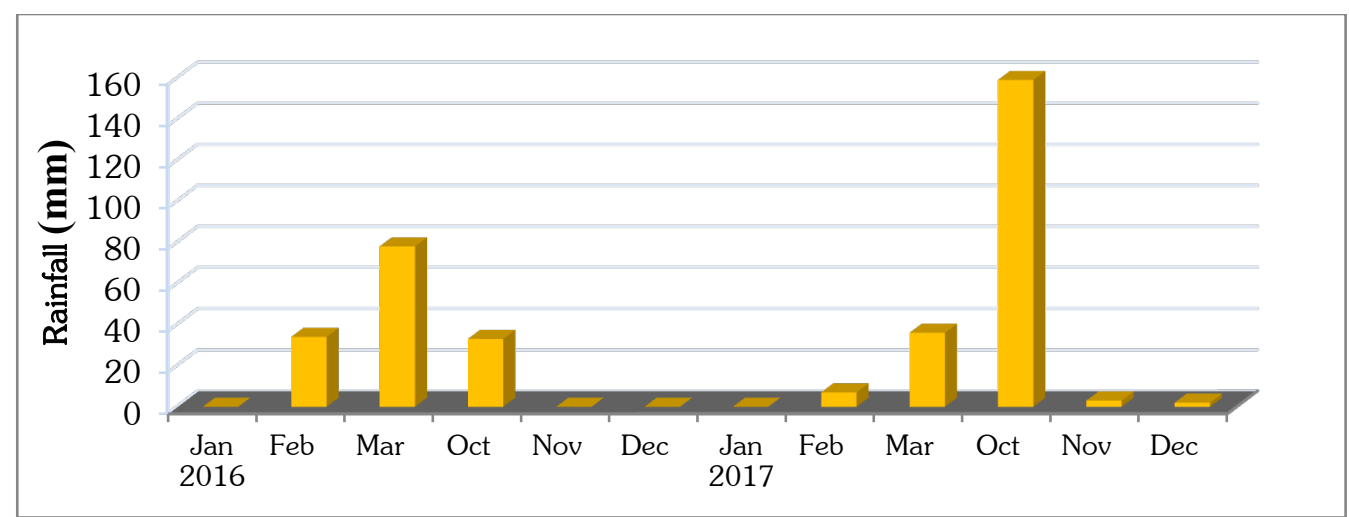

Fig. 2. Rainfall ( $\mathrm{mm}$ ) pattern in experimental location under Sylhet during experimentation.

The monthly temperature and rainfall of the experimental site are indicated in Figure 1 and 2 . The climatic data during experimentation shows that the average minimum and maximum temperature was $16.2{ }^{\circ} \mathrm{C}$ and $27.15^{\circ} \mathrm{C}$, respectively. On the contrary, the annual minimum and maximum temperature was $7.5{ }^{\circ} \mathrm{C}$ and 33.6 ${ }^{\circ} \mathrm{C}$ in the month of January and March, respectively. As indicated in Meteorological Station, Sylhet rainfall of the area is uni-modal, usually occurring during April to October, and total annual rainfall reached to $4217 \mathrm{~mm}$; whereas in December-January no rain at all and lowest amount of rainfall occurs in February followed by March (Figure 2). However, generally rainfall increases gradually from the month of May and continued up to September.

\section{Experimental materials and design}

Five different varieties of orange flesh sweet potato including local one viz. BARI Mishti Alu-4, BARI Mishti Alu-8, BARI Mishti Alu-12, BARI Mishti Alu-13 and Local check (var. Muli Alu) were used as experimental materials. Physiomorphological characteristics of sweet potato root tubers of experimented varieties are presented in Table 1. The experiment was laid out in a randomized complete block design (RCBD) with six dispersed replications. The size of each unit plot was $2 \mathrm{~m} \times 5 \mathrm{~m}$. The vines of sweet potato were planted on 20-25 October, 2016-17 and 2017-18 with maintaining the spacing at $60 \mathrm{~cm} \times 30$ $\mathrm{cm}$.

Table 1. Tuberous root characteristics of BARI released sweet potato and check (Muli Alu) varieties

\begin{tabular}{|c|c|c|c|c|c|}
\hline Variety & $\begin{array}{l}\text { Root shape } \\
\text { and size }\end{array}$ & Skin color & Flesh color & $\begin{array}{l}\text { B-carotene } \\
(\mathrm{mg} / 100 \mathrm{~g} \\
\text { fresh wt.) }\end{array}$ & $\begin{array}{l}\text { Dry } \\
\text { matter } \\
(\%)\end{array}$ \\
\hline BARI Mishti Alu-4 & $\begin{array}{l}\text { Round } \\
\text { elliptic }\end{array}$ & $\begin{array}{l}\text { Orange } \\
\text { brown }\end{array}$ & Orange & 4.41 & 26.00 \\
\hline BARI Mishti Alu-8 & $\begin{array}{l}\text { Round } \\
\text { elliptic }\end{array}$ & Purple Red & $\begin{array}{l}\text { Intermediate } \\
\text { yellow }\end{array}$ & 1.17 & 29.52 \\
\hline $\begin{array}{l}\text { BARI Mishti Alu- } \\
12\end{array}$ & $\begin{array}{l}\text { Long } \\
\text { elliptic }\end{array}$ & $\begin{array}{l}\text { Intermediate } \\
\text { Pink }\end{array}$ & Orange & 4.41 & 34.85 \\
\hline $\begin{array}{l}\text { BARI Mishti Alu- } \\
13\end{array}$ & $\begin{array}{l}\text { Long } \\
\text { elliptic }\end{array}$ & Cream & $\begin{array}{l}\text { Pale yellow } \\
\text { orange }\end{array}$ & 1.76 & 26.93 \\
\hline Local (Muli Alu) & $\begin{array}{l}\text { Long } \\
\text { elliptic }\end{array}$ & Light cream & White & 0.03 & 30.47 \\
\hline
\end{tabular}

Source: (Burgos, et al., 2009). 
The average size of vine cuttings ranges from $20-30 \mathrm{~cm}$ long with six to seven nodes. The field was fertilized with $70-25-88 \mathrm{~kg} \mathrm{ha}{ }^{-1}$ of NPK and 5-6 $\mathrm{t} \mathrm{ha}{ }^{-1}$ organic matter, respectively. Half of urea and all others fertilizer were used at final land preparation. Remaining part of $\mathrm{N}$ fertilizer was applied at the side of the row in two equal splits at 30 \& 60 days after transplanting followed by irrigation. One weeding and ear thing up was done 30 days after transplant. There was no remarkable disease and pest attack.

\section{Data collection and analysis}

The tuberous root was harvested variety wise on 25-28 March, 2016-17 1nd 2017-18 when drying of latex to white color in cut surface of roots and old leaves become yellowing to some extent. The data collection on morphological attributes was started at 60 days after planting and continued with an interval of 30 days until final harvest. At harvest, data of yield and yield components like length of vine, tuberous roots plant ${ }^{-1}$, weight of single root, root yield plot $^{-1}$ and root yield ha ${ }^{-1}$ were recorded from 10 randomly selected plants in each plot and yield of tuberous roots was recorded plot wise. The collected data were analyzed statistically using "STAR" software package and means were separated by LSD.

\section{Results and Discussion}

\section{Length of vine}

The main vine length of tested orange flesh sweet potato varieties measured at 120 days after transplanting of cutting showed significant variation (Table 2). The highest vine length was observed in local cultivar Muli Alu $(192.33 \mathrm{~cm})$. Rahaman et al. (2015) was also found that the vine length at 120 days after planting was ranged from 165.33 to $230.27 \mathrm{~cm}$ which is consistent to the present study. On the contrary, BARI Mishti Alu-13 produced the shortest vine $(119.00 \mathrm{~cm})$ at 120 days after planting. Vine length differs due to the genetic makeup present in the genotypes as well as tolerance to the acidic soil environment. Results are in agreement with the findings of Kareem (2013), reported that medium sized vine length ranges from $140-180 \mathrm{~cm}$ gave the best yield of sweet potato. Similar results were found in literature stated that the vine length differ from 220.17-264.43 cm due to their genetic make-up of sweet potato.

\section{Number of tuberous roots plant $^{-1}$}

The yield and yield contributing characters of the studied varieties were varied significantly. Results of two consecutive years of trial revealed that the sweet potato var. BARI Mishti Alu-12 produced the maximum number of tuberous roots (9.67) plant $^{-1}$. These results are closely related with those reported by Rahman et al. (2015) where the number of tuberous root per plant was about 7.13 in BARI Mishti Alu-7.

\section{Weight of single root $(\mathrm{g})$}

Overall, single weight of tuberous root in var. BARI Mishti Alu-12 was recorded significantly higher compared to other varieties in this trial. The sweet potato var. BARI Mishti Alu-12 produced biggest size of (166.67 g) tuberous root that was very close to the root weight $(163.33 \mathrm{~g})$ of local cultivar named Muli Alu. The bigger size of tuberous roots may be contributed higher root yields. Whereas, the var. BARI Mishti Alu-4 produced the smallest root size.

\section{Root yield plot $^{-1}$}

The tuberous root yields varied significantly with varieties used in this on-farm trial. The highest tuberous root weight plot $^{-1}(8.13 \mathrm{~kg})$ was observed in var. BARI Mishti Alu-12; whereas the lowest yield $(5.45 \mathrm{~kg})$ was obtained from local 
cultivar Muli Alu. On the other hand, statistically similar tuberous root yield per plot was produced by var. BARI Mishti Alu-8 and BARI Mishti Alu-13. Sen et al. (1988) stated that significant variations among the genotypes were happened might be due to the adoption of proper cultural management techniques.

\section{Root yield ( $\mathrm{t} \mathrm{ha}{ }^{-1}$ )}

The yield of tuberous roots varied markedly among five tested sweet potato varieties. The sweet potato var. BARI Mishti Alu-12 produced the maximum yield of tuberous root (40.63 $\mathrm{t} \mathrm{ha}^{-1}$ ) closely followed by BARI Mishti Alu-8 (30.40), BARI Mishti Alu-13 (29.70 $\left.\mathrm{t} \mathrm{ha}^{-1}\right)$ and BARI Mishti Alu-4 (29.64 $\left.\mathrm{t} \mathrm{ha}^{-1}\right)$ whereas the lowest yield of tuberous roots $\left(27.88 \mathrm{t} \mathrm{ha}^{-1}\right)$ was obtained from the local cultivar Muli Alu. Several researchers found that yield potentiality of sweet potato depends on the genetic make-up of plants (Naskar and Chowdhury, 1994; Siddique et al., 1988; Yooyongwech et al., 2014).

\section{Farmer's feedback}

Farmers' expressed that once the sweet potato was indigenized root crop cultivated by poor farmers with poor management and they used to believe it contributes very low nutritional supplement. At present they are very much conscious about vitamins, minerals, dietary fibre and protein which are containing sweet potato. As a result they changed attitude and shown keen interest to cultivate orange or yellow flesh sweet potato especially BARI Mishti Alu-12 due to its carotene rich and creating market demand in Sylhet.

Table 2. Tuberous root yield and yield contributing characters of sweet potato at FSRD site, Jalalpur, Sylhet

\begin{tabular}{lccccc}
\hline Varieties & $\begin{array}{c}\text { Length of } \\
\text { vines }(\mathrm{cm})\end{array}$ & $\begin{array}{c}\text { Tuberous } \\
\text { roots } \\
\text { plant }\end{array}$ & $\begin{array}{c}\text { Wt. of } \\
\text { single } \\
\text { tuberous } \\
\text { root }(\mathrm{g})\end{array}$ & $\begin{array}{c}\text { Tuberous } \\
\text { root yield } \\
\text { plot }^{-1}(\mathrm{~kg})\end{array}$ & $\begin{array}{c}\text { Tuberous } \\
\text { root yield } \\
\left.\text { (t ha } \text { h }^{-1}\right)\end{array}$ \\
\hline BARI Mishti Alu-4 & 164.33 & 5.00 & 97.67 & 5.93 & 29.64 \\
BARI Mishti Alu-8 & 149.67 & 5.33 & 111.00 & 6.08 & 30.40 \\
BARI Mishti Alu-12 & 119.67 & 9.67 & 166.67 & 8.13 & 40.63 \\
BARI Mishti Alu-13 & 119.00 & 7.33 & 148.33 & 5.94 & 29.70 \\
Local (Muli Alu) & 192.33 & 4.33 & 163.33 & 5.45 & 27.88 \\
\hline CV (\%) & 12.46 & 13.32 & 12.16 & 10.82 & 10.54 \\
LSD $(0.05)$ & 31.39 & 4.32 & 29.31 & 2.33 & 2.30 \\
\hline
\end{tabular}

\section{Economic analysis}

Regarding economic return, the highest gross margin and benefit cost ratio was obtained from sweet potato var. BARI Mishti Alu-12 and the lowest return was achieved from var. BARI Mishti Alu-4 with benefit cost ratio of 3.54 .

Table 3. Cost and return analysis of sweet potato varieties at FSRD site, South Surma, Sylhet

\begin{tabular}{lccccc}
\hline \multicolumn{1}{c}{ Varieties } & $\begin{array}{c}\text { Price of } \\
\text { root } \\
\text { tubers } \\
\left(\mathrm{Tk} \mathrm{kg}^{-1}\right)\end{array}$ & $\begin{array}{c}\text { Gross } \\
\text { return } \\
\left(\mathrm{Tk} \mathrm{ha}^{-1}\right)\end{array}$ & $\begin{array}{c}\text { Total variable } \\
\text { cost } \\
\left(\mathrm{Tk} \mathrm{ha}^{-1}\right)\end{array}$ & $\begin{array}{c}\text { Gross } \\
\text { margin } \\
\left(\mathrm{Tk} \mathrm{ha}^{-1}\right)\end{array}$ & $\begin{array}{c}\text { Benefit cost } \\
\text { ratio (BCR) }\end{array}$ \\
\hline $\begin{array}{l}\text { BARI Mishti Alu-4 } \\
\text { BARI Mishti Alu-8 }\end{array}$ & 15.00 & 444600 & 125600 & 319000 & 3.54 \\
BARI Mishti Alu- & 17.00 & 456000 & 125600 & 330400 & 3.63 \\
12 & 690710 & 125600 & 565110 & 5.50 \\
BARI Mishti Alu- & 15.00 & 445500 & 125600 & 319900 & 3.55 \\
13 Local (Muli Alu) & 18.00 & 501840 & 125600 & 376240 & 3.99 \\
\hline
\end{tabular}


Though the local cultivar (Muli Alu) produced lower tuberous root yields but it provided considerable gross margin and BCR which closed to BARI Mishti Alu12. It is due to higher price of tuberous root in the local market.

\section{Conclusions}

Of the orange flesh sweet potato varieties and cultivar evaluated in Sylhet region, the high yielder sweet potato var. BARI Mishti Alu-12 had acceptable tuberous root yields with maximum economic profit. Though the local cultivar (Muli Alu) of sweet potato was low yielder but already created local market demands for its sweetness.

\section{Acknowledgement}

The authors extend their gratitude to the Tuber Crop Research Center of Bangladesh Agricultural Research Institute (BARI), for providing the vines of orange flesh sweet potato varieties. The two organizations Metrological Department and Soil Resource Development Institute of Sylhet district are thanked for the cooperation accorded.

\section{References}

Ahmed, M. D. S., M. A. Quadir, M. K. R. Bhuiyan and T. R. Dayal. 1998. Genetic diversity of sweet potato (Ipomoea batatas L.). Bangladesh J. Root Crops. 24: 11-15.

Away, A. K., M. P. Nawiri, H. N. Nyambaka. 2013. Nutrient variation in colored varieties of Ipomea batatas grown in Vihiga County, Western Kenya. Int. Food Res. J. 20(2): 819-825.

Burgos, G., R. Caprio, C. Sanchez, P. Sosa, E. Porras, J. Espinoza and W. Gruneberg. 2009. Guide for using the RHS color chart for selecting for high $\beta$-Carotene Sweet potato. Poster at ISTRC, Lima, Peru.

Burri, B. J. 2011. Evaluating sweet potato as an intervention food to prevent vitamin-A deficiency. Comp. Rev. Food Sci. Food Safe. 10:118-130.

Delowar, H. K. M and M. A. Hakim. 2014. Effect of salinity levels on the morphophysiological characteristics and yield attributes of sweet potato genotypes. Int. J. Sci. Res., 10: 929-934

Kareem, I. 2013. Growth, yield and phosphorus uptake of sweet potato (Ipomoea batatas) under the influence phosphorus fertilizers. Res. J. Chem. Environ. Sci., 1: 50-55.

Kaspar, K. L., J. S. Park, C. R. Brown, K. Weller, C. F. Ross, B. D. Mathison and B. P. Chew. 2013. Sensory evaluation of pigmented flesh potatoes (Solanum tuberosum L.). Food Nutr. Sci. 4:77-81.

Laurie, S. M. and S. M. Van Heerden. 2012. Consumer acceptability of four products made from beta-carotene-rich sweet potato. Afr. J. Food Sci. 6:96103.

Li, P. G. and T. H. Mu. 2012. Sweet potato: health benefits, production and utilization in China. In Potatoes: Production, Consumption and Health Benefits. C. Caprara (edn.). Nova Science Publishers. pp. 127-172.

Naskar, S. K. and S. R. Chowdhury, 1994. Growth and yield response of eight sweet potato lines. Indian J. Plant Physiol., 37: 200-202. 
Otoo, J. A., A. Missah and A. G. Carson. 2001. Evaluation of sweet potato for early maturity across different agro-ecological zones in Ghana. Afr. Crop Sci. J., 9: 25-32.

Rahaman, E. H. M. S., A. A. Mahmud, M. Hossain, H. C. Mohanta, M. A. Rahman, M. S. I. Haque, M. E. Khan, M. M. Hossain, M. M. Hasan and B. Merideth. 2015. Field performance of sweet potato varieties in saline zone of Bangladesh. Bangladesh Hort. 1(1 \& 2): 67-76.

Rahman, H., A. F. M. S. Islam, M. M. Abdul and R. Tabassum. 2015. Morphophysiological evaluation of sweet potato (Ipomoea batatas L.) genotypes in acidic soil. Asian J. Crop Sci. 7 (4): 267-276.

Siddique, M. A., A. T. M. Hassanuzzaman and H. Akbar. 1988. Growth and yield of three high-yielding sweet potato genotypes. Bangladesh J. Agric. 13: 139146.

Teow, C. C., V. D. Truong, R. F. Mc Feeters, R. L. Thompson, K.V. Pecota and G. C. Yencho. 2007. Antioxidant activities, phenolic and b-carotene contents of sweet potato genotypes with varying flesh colors. Food Chem. 103: 829838.

Yooyongwech, S., T. Samphumphuang, C. Theerawitaya and S. Cha-Um, 2014. Physio-morphological responses of sweet potato (Ipomoea batatas L.) genotypes to water-deficit stress. Plant Omics J. 7: 361-368. 